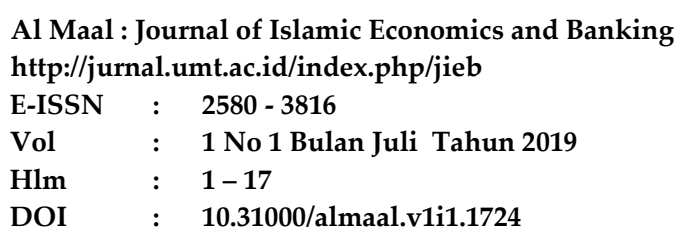

\title{
Faktor - Faktor Yang Mempengaruhi Penyaluran Pembiayaan Perbankan Syariah Indonesia Periode 2009 - 2019
}

\author{
Warto ${ }^{1, *}$, R. Bambang Budhijana ${ }^{2}$ \\ ${ }^{1}$ Prodi Perbankan Syariah, Universitas Muhammadiyah Tangerang, Tangerang, Indonesia \\ ${ }^{2}$ Prodi Manajeman Keuangan dan Perbankan, STIE Indonesia Banking School, Jakarta, \\ Indonesia \\ *Email:warto@umt.ac.id
}

\section{ABSTRACT}

This study uses the Sharia Commercial Bank and the Sharia Business Unit as a whole as a unit of research object, with the research period from 2009-2019 (in the quarterly period). The analysis technique used is multiple linear regression, while hypothesis testing uses the t-test to test the effect of variables partially, and the F-test to test the effect of variables simultaneously with a significance level of 5\% or 0.05. Based on the research, it was found that Third Party Funds (TPF) had a positive and significant effect on the distribution of Islamic Banking financing. Non Performing Financing (NPF) has a positive and insignificant effect on the distribution of bank financing. While Sharia Bank Indonesia Certificates (SBIS) have a negative and significant effect on the distribution of bank financing.

Keywords: Financing Distributed Islamic Banking; Third Party Funds; Non Performing Financing; Bank Indonesia Syariah Certificates

\begin{abstract}
ABSTRAK
Penelitian ini menggunakan Bank Umum Syariah dan Unit Usaha Syariah secara keseluruhan sebagai satu unit obyek penelitian, dengan periode penelitian dari tahun 2009-2019 (secara tri wulanan). Teknik analisis yang digunakan adalah regresi linier berganda, sementara uji hipotesis menggunakan uji-t untuk menguji pengaruh variabel secara parsial, serta uji-F untuk menguji pengaruh variabel secara serempak dengan tingkat signifikansi 5\% atau 0,05. Berdasarkan penelitian diperoleh hasil bahwa Dana Pihak Ketiga (DPK) berpengaruh positif dan signifikan terhadap penyaluran pembiayaan Perbankan Syariah. Non Performing Financing $(N P F)$ berpengaruh positif dan tidak signifikan terhadap penyaluran pembiayaan perbankan. Sementara Sertifikat Bank Indonesia Syariah (SBIS) berpengaruh negatif dan signifikan terhadap penyaluran pembiayaan perbankan.
\end{abstract}

Kata Kunci: Pembiayaan Yang Disalurkan (PYD); Dana Pihak Ketiga (DPK); Non Performing Financing (NPF); Sertifikat Bank Indonesia Syariah (SBIS) 


\section{Pendahuluan}

Perbankan Syariah adalah lembaga intermediasi yang menjalankan empat fungsi utama, yaitu: menerima penitipan uang dari masyarakat, menyalurkan uang kembali kepada masyarakat dalam bentuk pembiayaan, dan memberikan pelayanan jasa lalu lintas keuangan dan pelayanan sosial.

Dalam fungsinya menerima penitipan uang, terlihat peningkatan yang cukup signifikan hal ini dapat dilihat dari total Dana Pihak Ketiga yang diterimanya, dari tahun 2009 yang hanya sebesar Rp. 38,040 miliar pada tahun 2019 menjadi Rp. 382,734 miliar.

Dalam hal penyaluran pembiayaan, terbukti Bank Syariah mampu menyalurkannya dana secara optimal. Hal ini dapat dilihat dari nilai Financing to Deposit Ratio (FDR) yang mencapai rata-rata 89\%-107\%.

Pertanyaannya adalah bagaimana fungsi intermediasi Bank Syariah di Indonesia jika dilihat dari segi kuantitasnya? Pertanyaan ini menjadi tantangan bagi pengembangan Bank Syariah di Indonesia. Market share Perbankan Syariah setiap tahun memang selalu meningkat. Tahun 2005 misalnya, market share Perbankan Syariah berkisar pada angka $1,78 \%$ sedangkan satu tahun berikutnya meningkat menjadi 2,03\%. Pada bulan Oktober akhir 2011 sebesar 4,47\%. Pada Oktober 2017 sebesar 5,44\%. Di awal tahun 2019 angka tersebut naik menjadi 5,94\%. Namun peningkatan ini masih sangat kecil dibandingkan dengan besarnya potensi pasar yang ada. Angka tersebut menunjukkan bahwa secara kuantitas, fungsi intermediasi Bank Syariah belum signifikan.

Dari uraian di atas kita bisa menurunkan pertanyaan, apa hubungan antara DPK dengan fungsi intermediasi Bank Syariah? Bank berperan sebagai pihak yang mempertemukan antara komponen masyarakat yang memerlukan 'tempat' untuk menyimpan dana mereka dengan komponen masyarakat lain yang membutuhkan dana. Oleh karena itu, fungsi intermediasi akan dapat diimplementasikan dengan baik jika bank mampu menjaga perputaran dana secara sirkular antara pihak yang kelebihan dan pihak yang kekurangan dana. Bukan hanya kualitas perputaran dana yang harus dijaga oleh dunia perbankan, namun kuantitas atau volume dana yang harus diputar juga mempengaruhi fungsi intermediasinya. Kalau bank hanya berkemampuan menghimpun dana dalam jumlah kecil, niscaya volume dana yang dapat disalurkan juga kecil. Seandainya hal ini terjadi, maka fungsi intermediasi bank tidak berjalan optimal karena bank hanya mampu mempertemukan sebagian kecil pihak yang surplus dan pihak yang defisit. Berdasarkan hal tersebut, maka untuk menjalankan fungsi intermediasi, bank harus mampu memobilisasi dana dalam jumlah besar, sehingga semakin besar jumlah pihak surplus dan defisit yang dapat dipertemukan oleh pihak Bank Syariah Indonesia.

Besar kecilnya penyaluran dana yang diberikan Bank Syariah sangat dipengaruhi oleh besar kecilnya Dana Pihak Ketiga (DPK), akan tetapi berdasarkan data statistik Perbankan Syariah dari Bank Indonesia perlu dilakukan penelitian lebih lanjut karena besarnya pertumbuhan DPK tidak selalu membuat Bank Syariah menaikkan pertumbuhan dana yang disalurkan kepada masyarakat.

Besarnya rata-rata Dana Pihak Ketiga (DPK), Capital Adequacy Ratio (CAR), Non Performing Financing (NPF), Sertifikat Bank Indonesia Syariah (SBIS), perlu menjadi pertimbangan dalam meningkatkan penyaluran dana. 
Berdasarkan data laporan Perbankan Syariah yang di publikasi oleh OJK dapat kita lihat bahwa DPK mempunyai pergerakan yang meningkat dari tahun 2009-2019 searah dengan pergerakan pembiayaan (indikasi positif). CAR mempunyai pergerakan yang meningkat dari tahun 2009-2019 searah dengan pergerakan pembiayaan (indikasi positif), dan kemudian menurun dari tahun 2007-2019 tidak searah dengan pergerakan pembiayaan (indikasi negatif). NPF mempunyai pergerakan yang meningkat dari tahun 2009-2019 searah dengan pergerakan pembiayaan (indikasi positif). SBIS mempunyai pergerakan yang naik-turun dari tahun 2009-2019 searah dengan pergerakan pembiayaan (indikasi negatif).

Mengingat pentingnya penyaluran dana bagi pertumbuhan ekonomi negara dan adanya banyak faktor yang mempengaruhi penyaluran dana pada sektor-sektor ekonomi dalam masyarakat, maka perlu dilakukan penelitian lebih lanjut yang bertujuan untuk mengetahui faktor-faktor apa saja yang mempengaruhi pembiayaan Perbankan Syariah di Indonesia. Dengan diketahuinya faktor-faktor tersebut, maka Perbankan Syariah dapat menyusun langkah antisipatif dan strategis terhadap segala perubahan yang terjadi pada variabel-variabel yang menjadi faktor-faktor berpengaruh tersebut. Dengan demikian asset perbankan dapat ditingkatkan dan

\section{KAJIAN LITERATUR Teori Pembiayaan Syariah}

Fungsi utama Perbankan Syariah adalah mengumpulkan dana dan menyalurkan pembiayaan. Fungsi ini yang lazim disebut sebagai fungsi intermediasi keuangan. Hal tersebut telah diatur dalam pasal 19 ayat (1) dan (2) UU Republik Indonesia No.21 Tahun 2008 tentang Perbankan Syariah. Penyaluran dana yang terdapat di Bank Syariah dengan yang terdapat di bank konvensional mempunyai perbedaan yang esensial, baik dalam hal nama, akad, maupun transaksinya. Dalam perbankan konvensional penyaluran dana ini dikenal dengan nama kredit sedangkan diPerbankan Syariah disebut pembiayaan.

Perbedaan pengertian antara kredit dan pembiayaan adalah bahwa kredit mengharuskan debitur mengembalikan pinjaman dengan pemberian bunga kepada bank. Sementara pembiayaan yang berdasarkan prinsip syariah, pengembalian pinjaman dan bagi hasil didasarkan kepada kesepakatan antara bank dan debitur. Misalnya, pembiayaan dengan prinsip jual beli ditujukan untuk membeli barang, sedangkan yang menggunakan prinsip sewa ditujukan untuk mendapat jasa. Prinsip bagi hasil digunakan untuk usaha kerjasama yang ditujukan guna mendapatkan barang dan jasa.

Ketentuan tentang pembiayaan Bank Syariah tercantum dalam UU Republik Indonesia, No. 21/ 2008, Tentang Perbankan Syariah, Bab I, Ketentuan Umum, Pasal 1, ayat 25 , yang berbunyi:

Pembiayaan adalah penyediaan dana atau tagihan yang dipersamakan dengan itu berupa:

a) transaksi bagi hasil dalam bentuk mudharabah dan musyarakah;

b) transaksi sewa-menyewa dalam bentuk ijarah atau sewa beli dalam bentuk ijarah muntahiya bittamlik;

c) transaksi jual beli dalam bentuk piutang murabahah, salam, dan istishna'; 
d) transaksi pinjam meminjam dalam bentuk piutang qardh; dan

e) transaksi sewa-menyewa jasa dalam bentuk ijarah untuk transaksi multijasa.

berdasarkan persetujuan atau kesepakatan antara Bank Syariah dan/atau UUS dan pihak lain yang mewajibkan pihak yang dibiayai dan/atau diberi fasilitas dana untuk mengembalikan dana tersebut setelah jangka waktu tertentu dengan imbalan ujrah, tanpa imbalan, atau bagi hasil (UU RI No. 21 Tahun 2008 Tentang Perbankan Syariah)

\section{Dana Pihak Ketiga (DPK)}

Sebagaimana halnya bank konvensional, Bank Syariah memainkan peran yang sangat vital dan strategis. Eksistensi Bank Syariah dapat dijadikan sebagai salah satu satu dari indikator perkembangan ekonomi Islam. Semakin besar market share perbankan syariah, maka semakin banyak komponen dalam masyarakat yang menggunakan berbagai transaksi syariah.

Komposisi sumber dana yang dihimpun Bank Syariah setidaknya terdiri dari tiga komponen, yaitu modal, pinjaman antar bank dan DPK. Sebagaimana halnya dalam perbankan konvensional, dana yang terhimpun dari masyarakat merupakan komponen terpenting dalam penghimpunan dana (funding) di dunia perbankan.

Sumber dana dari masyarakat ini disebut dengan simpanan atau Dana Pihak Ketiga (DPK), yang dalam UU No. 21 tahun 2008 Bab I ayat 20 didefinisikan sebagai dana yang dipercayakan oleh nasabah kepada Bank Syariah dan/atau UUS berdasarkan akad wadi'ah atau akad lain yang tidak bertentangan dengan prinsip syariah dalam bentuk Giro, Tabungan, atau bentuk lainnya yang dipersamakan dengan itu. Tabungan adalah simpanan berdasarkan akad wadi'ah atau investasi dana berdasarkan akad mudharabah atau akad lain yang tidak bertentangan dengan prinsip syariah yang penarikannya hanya dapat dilakukan menurut syarat dan ketentuan tertentu yang disepakati, tetapi tidak dapat ditarik dengan cek, bilyet giro, dan/atau alat lainnya yang dipersamakan dengan itu. Sedangkan deposito adalah investasi dana berdasarkan akad mudharabah atau akad lain yang tidak bertentangan dengan prinsip syariah yang penarikannya hanya dapat dilakukan pada waktu tertentu berdasarkan akad antara nasabah penyimpan dan Bank Syariah dan/atau UUS. Giro adalah simpanan berdasarkan akad wadi'ah atau akad lain yang tidak bertentangan dengan prinsip syariah yang penarikannya dapat dilakukan setiap saat dengan menggunakan cek, bilyet giro, sarana perintah pembayaran lainnya, atau dengan perintah pemindahbukuan (UU RI No. 21 Tahun 2008 tentang Perbankan Syariah).

Sumber dana ini merupakan sumber dana terpenting bagi kegiatan operasi suatu bank dan merupakan ukuran keberhasilan bank jika mampu membiayai operasinya dari sumber dana jenis ini. DPK relatif mudah untuk diperoleh, karena DPK banyak tersedia di masyarakat. Namun demikian DPK tergolong mahal, karena pihak bank harus menyediakan sebanyak mungkin fasilitas bagi nasabah yang menyimpan dananya di bank bersangkutan.

\section{Sertifikat Bank Indonesia Syariah}

Berdasarkan Frequently Asked Questions (FAQS) atas Peraturan Bank Indonesia Nomor 10/11/PBI/2008 tentang Sertifikat Bank Indonesia Syariah, dijelaskan bahwa Sertifikat Bank Indonesia Syariah (SBI Syariah) adalah "Surat berharga berdasarkan 
prinsip Syariah berjangka waktu pendek dalam mata uang Rupiah yang diterbitkan oleh Bank Indonesia".

Peraturan Bank Indonesia tentang Sertifikat Bank Indonesia Syariah dikeluarkan dan ditujukan sebagai salah satu instrumen operasi pasar terbuka dalam rangka pengendalian moneter yang dilakukan berdasarkan prinsip Syariah (Pasal 2 ayat (1) dan (2) Peraturan Bank Indonesia Nomor 10/36/PBI/2008 Operasi Moneter Syariah).

Dalam Peraturan Bank Indonesia itu disebutkan, bahwa Sertifikat Bank Indonesia Syariah diterbitkan melalui mekanisme lelang (Pasal 6 ayat (1) ). Adapun pihak yang berhak mengikuti lelang adalah Bank Syariah, Unit Usaha Syariah, dan pialang yang bertindak untuk dan atas nama Bank Syariah atau Unit Usaha Syariah (Pasal 7 ayat (3) ). Dan hanya Bank Syariah atau Unit Usaha Syariah yang dapat mengikuti lelang Sertifikat Bank Indonesia Syariah jika memenuhi persyaratan Financing to Deposit Ratio (FDR) yang ditetapkan oleh Bank Indonesia (Pasal 7 ayat (2) ).

SBI Syariah merupakan surat berharga berdasarkan prinsip syariah berjangka waktu pendek dalam mata uang rupiah yang diterbitkan oleh BI. Ketentuan SBI Syariah diterbitkan untuk meningkatkan efektifitas pelaksanaan pengendalian moneter berdasarkan pada prinsip syariah. Sebenarnya istrumen ini merupakan instrumen moneter yang disediakan berdasarkan permintaan Perbankan Syariah, yang merasa telah diperlakukan beda dengan bank konvensional. Dimana instrument SBI yang disediakan untuk bank konvensional lebih baik dan memiliki return yang lebih tinggi.

Melihat perbedaannya dengan SBI konvensional, cukup jelas, bahwa [1] SBI Syariah tidak mendapatkan return berupa bunga hal yang berbeda dengan SBI Konvensional, [2] untuk menempatkan dananya pada SBI Syariah, bank-Bank Syariah harus memiliki Financing to Deposit Ratio (FDR) minimal sekitar 80\%.

Selanjutnya, untuk menerbitkan SBI Syariah, sesuai dengan PBI No. 10/11/PBI/2008 tentang SBI Syariah, bahwa SBI Syariah diterbitkan melalui mekanisme lelang. Pihak yang berhak mengikuti lelang adalah Bank Umum Syariah (BUS), Unit Usaha Syariah (UUS), dan pialang yang bertindak untuk dan atas nama BUS atau UUS. Hanya, BUS atau UUS baru dapat mengikuti lelang SBI Syariah jika memenuhi persyaratan Financing to Deposit Ratio yang ditetapkan oleh BI.

BUS atau UUS dapat merepokan SBI Syariah miliknya kepada BI dengan terlebih dahulu menandatangani perjanjian pengagunan SBI Syariah dalam rangka Repo SBI Syariah. Terhadap Repo SBI Syariah, BI akan mengenakan biaya kepada BUS atau UUS.

\section{Metode Penelitian}

Metode penelitian yang digunakan dalam riset ini adalah metode kuantitatif menggunakan data skunder sebagai dasar interpretasi dan analisis agar didapat suatu kesimpulan yang digunakan untuk mengetahui sesuatu tentang populasi.

Penelitian ini diolah menggunakan program E-Views 4.1 dan meliputi data sekunder. Data yang diolah merupakan data sekunder yang diperoleh dari data statistik perbankan syariah oleh Bank Indonesia.

\section{Populasi dan Sampel}


Populasi yang dijadikan objek penelitian adalah seluruh perbankan yang terdaftar di Bank Indonesia selama periode tahun 2009 sampai dengan 2019 sejumlah 14 Bank Umum Syariah dan 20 Unit Usaha Syariah, seperti nampak pada Tabel 1 berikut ini:

Tabel 1. Daftar Sampel Penelitian

\begin{tabular}{|c|c|c|}
\hline No & Nama Perusahaan Perbankan & Kelompok Bank \\
\hline 1 & PT Bank Syariah Muamalat Indonesia & Bank Umum Syariah \\
\hline 2 & PT Bank Syariah Mandiri & Bank Umum Syariah \\
\hline 3 & PT Bank Syariah Mega Indonesia & Bank Umum Syariah \\
\hline 4 & PT Bank Syariah BRI & Bank Umum Syariah \\
\hline 5 & PT Bank Syariah Bukopin & Bank Umum Syariah \\
\hline 6 & PT Bank Panin Syariah & Bank Umum Syariah \\
\hline 7 & PT Bank Victoria Syariah & Bank Umum Syariah \\
\hline 8 & PT BCA Syariah & Bank Umum Syariah \\
\hline 9 & PT Bank Jabar dan Banten & Bank Umum Syariah \\
\hline 10 & PT Bank Syariah BNI & Bank Umum Syariah \\
\hline 11 & PT Maybank Indonesia Syariah & Bank Umum Syariah \\
\hline 12 & PT Bank Aceh Syariah & Bank Umum Syariah \\
\hline 13 & PT BPD Nusa Tenggara Barat Syariah & Bank Umum Syariah \\
\hline 14 & PT. Bank Tabungan Pensiunan Nasional Syariah & Bank Umum Syariah \\
\hline 15 & PT Bank Danamon Indonesia & Unit Usaha Syariah \\
\hline 16 & PT Bank Permata & Unit Usaha Syariah \\
\hline 17 & PT Bank Maybank Indonesia & Unit Usaha Syariah \\
\hline 18 & PT Bank CIMB Niaga & Unit Usaha Syariah \\
\hline 19 & PT Bank OCBC NISP & Unit Usaha Syariah \\
\hline 20 & PT Bank Sinarmas & Unit Usaha Syariah \\
\hline 21 & PT Bank Tabungan Negara (Persero) & Unit Usaha Syariah \\
\hline 22 & $P T B P D D K I$ & Unit Usaha Syariah \\
\hline 23 & PT BPD Daerah Istimewa Yogyakarta & Unit Usaha Syariah \\
\hline 24 & PT BPD Jawa Tengah & Unit Usaha Syariah \\
\hline 25 & PT BPD Jawa Timur & Unit Usaha Syariah \\
\hline 26 & PT BPD Sumatera Utara & Unit Usaha Syariah \\
\hline 27 & PT BPD Jambi & Unit Usaha Syariah \\
\hline 28 & PT BPD Sumatera Barat & Unit Usaha Syariah \\
\hline 29 & PT BPD Riau dan Kepulauan Riau & Unit Usaha Syariah \\
\hline
\end{tabular}


Faktor-Faktor Yang Mempengaruhi Penyaluran Pembiayaan Perbankan Syariah Di Indonesia Periode 2009 - 2019

\begin{tabular}{ccc}
30 & $P T$ BPD Sumatera Selatan dan Bangka Belitung & Unit Usaha Syariah \\
31 & $P T$ BPD Kalimantan Selatan & Unit Usaha Syariah \\
32 & $P T$ BPD Kalimantan Barat & Unit Usaha Syariah \\
33 & $P D$ BPD Kalimantan Timur & Unit Usaha Syariah \\
34 & $P T$ BPD Sulawesi Selatan dan Sulawesi Barat & Unit Usaha Syariah \\
\hline \multicolumn{3}{r}{ Sumber: Otoritas Jasa Keuangan $($ OJK), 2019}
\end{tabular}

\section{Definisi Operasional Variabel}

Definisi variabel yang terdapat dalam riset dan analisis ini adalah sebagai berikut:

Dana Pihak Ketiga/DPK $(\mathrm{X} 1)=$ DPK adalah dana yang dipercayakan oleh nasabah kepada Bank Syariah dan/atau Unit Usaha Syariah berdasarkan akad wadi'ah atau akad lain yang tidak bertentangan dengan prinsip syariah dalam bentuk Giro, Tabungan, Deposito atau bentuk lainnya yang dipersamakan dengan itu (UU No. 21 tahun 2008).

Non Performing Finance/NPF $(X 2)=$ NPF adalah tingkat pengembalian pembiayaan yang diberikan deposan kepada bank, dengan kata lain NPF merupakan tingkat pembiayaan macet pada bank tersebut. NPF diketahui dengan cara menghitung Pembiayaan Non Lancar terhadap Total Pembiayaan (Purwanto, 2011).

Sertifikat Bank Indonesia Syariah/SBIS (X3) = SBIS adalah Sertifikat Bank Indonesia Syariah (SBI Syariah) adalah "Surat berharga yang berdasarkan prinsip syariah, berjangka waktu pendek, dalam mata uang rupiah yang diterbitkan oleh Bank Indonesia".

Pembiayaan Yang Disalurkan/PYD (Y1) = adalah penyediaan dana atau tagihan yang dipersamakan dengan itu, berupa:

a) Transaksi bagi hasil dalam bentuk mudharabah dan musyarakah;

b) Transaksi sewa-menyewa dalam bentuk ijarah atau sewa beli dalam bentuk ijarah muntahiya bittamlik;

c) Transaksi jual beli dalam bentuk piutang murabahah, salam, dan istishna';

d) Transaksi pinjam meminjam dalam bentuk piutang qardh; dan

Transaksi sewa-menyewa jasa dalam bentuk ijarah untuk transaksi multijasa berdasarkan persetujuan atau kesepakatan antara Bank Syariah dan/atau UUS dan pihak lain yang mewajibkan pihak yang dibiayai dan/atau diberi fasilitas dana untuk mengembalikan dana tersebut setelah jangka waktu tertentu dengan imbalan ujrah, tanpa imbalan, atau bagi hasil. (UU Republik Indonesia, No. 21/ 2008 Tentang Perbankan Syariah, Bab I, Ketentuan Umum, Pasal 1, ayat 25).

\section{Pengumpulan Data dan Sumber Data}

Data utama yang digunakan dalam riset ini menggunakan data skunder yang diambil dari data statistik Bank Indonesia, statistik OJK dan Laporan keuangan Bank Syariah Indonesia dan dari kurun waktu 2009-2019 yang dipublikasikan melalui website Bank Indonesia dan website OJK. 
Kelengkapan data lainnya, akan digunakan data-data sekunder resmi yang tersedia pada lembaga-lembaga pemerintahan, seperti : Badan Pusat Statistik.

Teknik pengumpulan data yang digunakan dalam penelitian ini adalah teknik dokumentasi, yaitu teknik pengumpulan data dengan cara mempelajari, mengklasifikasikan dan menggunakan data sekunder berupa catatan-catatan, laporanlaporan, khususnya laporan keuangan bank yang berhubungan dengan penelitian. Setelah data terkumpul selanjutnya diperiksa dan ditabulasikan sesuai dengan kebutuhan analisis, sehingga diperoleh analisis yang baik dan dapat dipertanggungjawabkan.

\section{Metode Analisis Data}

Metode analisis yang digunakan dalam penelitian ini adalah regresi linier berganda, yaitu metode statistika yang digunakan untuk membentuk model hubungan antara variabel terikat (dependen; respon; Y) dengan satu atau lebih variabel bebas (independen, predictor, X). Karena terdapat lebih dari 1 variabel bebas, maka disebut sebagai regresi linier berganda. (Kurniawan, 2008]

Dari definisi operasional variabel di atas $(P Y D \rightarrow Y 1, D P K \rightarrow X 1, N P F \rightarrow X 2$ dan $S B I S \rightarrow X 3)$ maka terbentuk model persamaan matematika regresi berganda untuk penelitian ini sebagai berikut:

$$
\begin{aligned}
& P Y D=f(D P K, N P F, \text { SBIS }) \\
& Y 1=b o+b 1 X 1+b 2 X 2+b 3 X 3+e i
\end{aligned}
$$

Keterangan:

Y1 = Pembiayaan Yang Disalurkan

$\mathrm{X} 1$ = Dana Pihak Ketiga

$\mathrm{X} 2$ = Non Performing Finance

X3 = Sertifikat Bank Indonesia Syariah

Di dalam model Regresi Linier Berganda terdapat dua cara untuk melakukan estimasi, yaitu estimasi yang dilakukan secara manual dan dengan mengunakan software (Sofriza, 2011)

\section{Hasil dan Pembahasan}

Karena data yang digunakan adalah data sekunder maka untuk menentukan ketepatan model perlu dilakukan pengujian atas beberapa asumsi klasik yang digunakan yaitu: Uji Normalitas, Uji Multikolonieritas, Uji Autokorelasi dan Uji Heteroskedastisitas yang secara rinci dapat dijelaskan sebagai berikut.

\section{Uji Normalitas}

Uji Normalitas bertujuan untuk menguji apakah dalam model regresi variabel pengganggu atau residual memiliki distribusi normal. Model regresi yang baik adalah memiliki distribusi data normal atau mendekati normal.

Hasil Uji Normalitas dengan menggunakan E-Views adalah sebagai berikut; 


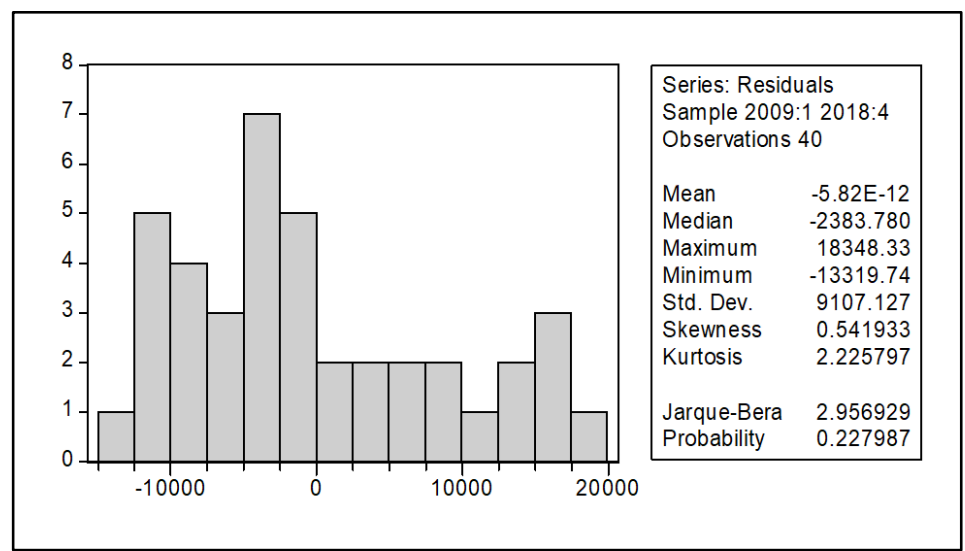

Gambar 1. Hasil Uji Normalitas

\section{Hipotesa:}

Ho: residual terdistribusi normal

Ha: residual tidak terdistribusi normal

Bila Prob J-B stat $>\alpha$, Ho diterima dan Ha ditolak

Bila Prob J-B stat $<\alpha$, Ho ditolak dan Ha diterima

Dari hasil Uji Normalitas di atas Prob J-B stat $=0.227987>0.05$, berarti Ho diterima. Kesimpulan: Secara statistik, residual terdistribusi secara normal

\section{Uji Multikolonieritas}

Dalam penelitian konvensional uji Multikolonieritas bertujuan untuk mengetahui apakah dalam model regresi ditemukan adanya korelasi antar variabel bebas (independen). Model regresi yang baik seharusnya tidak terjadi korelasi diantara variabel independen (Ghozali, 2009). Berdasarkan Correlation Matrix diperoleh hasil sebagai berikut;

Tabel 2. Correlation Matrix

\begin{tabular}{ccccc}
\hline & $P Y D$ & $D P K$ & $N P F$ & $S B I S$ \\
\hline$P Y D$ & 1.000000 & 0.993148 & 0.918504 & 0.849802 \\
$D P K$ & 0.993148 & 1.000000 & 0.915805 & 0.875022 \\
$N P F$ & 0.918504 & 0.915805 & 1.000000 & 0.818832 \\
SBIS & 0.849802 & 0.875022 & 0.818832 & 1.000000 \\
\hline
\end{tabular}

Dari hasil di atas terlihat bahwa terdapat korelasi antar variabel bebas variabel DPK dan NPF $=0.915805$, variabel DPK dan SBIS $=0.875022$ serta variabel NPF dan SBIS $=0.818832$ tergolong cukup tinggi yaitu di atas $80 \%$. Secara konvensional tingginya nilai korelasi antar variabel independen mengakibatkan kesulitan dalam membedakan pengaruh masing-masing variable bebas terhadap variabel tidak bebas. 
Untuk mengetahui apakah tingginya nilai korelasi antar variabel bebas berakibat baik atau buruk terhadap model regresi dalam penelitian ini maka perlu dilakukan uji Wald. Dari Uji Wald diperoleh hasil sebagai berikut:

Tabel. 3. Hasil Uji Wald

\begin{tabular}{|c|c|c|c|}
\hline Test Statistic & Value & $d f$ & Probability \\
\hline$F$-statistic & 5.541090 & $(1,36)$ & 0.0242 \\
\hline Chi-square & 5.541090 & 1 & 0.0186 \\
\hline \multicolumn{2}{|c|}{ Normalized Restriction $(=0)$} & Value & Std. Err. \\
\hline \multicolumn{2}{|c|}{$C(4)$} & -2.405531 & 1.021912 \\
\hline
\end{tabular}

Dari hasil uji Wald dikatakan bahwa SBIS tidak boleh dibuang karena prob t-stat $0.0242<0.05$. Penghilangan variabel bebas yang mengandung multikolinearitas justeru akan mengubah interpretasi dari persamaan regresinya sehingga penghilangan variabel tersebut tidak diperbolehkan. Dengan kata lain, sekalipun variabel SBIS mengandung multikolinearitas yang tinggi namun ia memiliki pengaruh signifikan terhadap variabel tidak bebas. Sehingga pembuangan variabel SBIS dari persamaan akan berakibat buruk pada hasil penelitian.

\section{Uji Autokorelasi}

Uji Autokorelasi bertujuan untuk menguji apakah dalam model regresi linear ada korelasi antara kesalahan pengganggu pada periode $t$ dengan kesalahan pengganggu pada periode t-1 (sebelumnya). Jika terjadi korelasi maka dinamakan ada problem autokorelasi. (Ghozali, 2009). Karena data yang diolah dalam penelitian ini menggunakan data times series, maka perlu dilakukan pendeteksian autokorelasi.

Untuk melakukan uji autokorelasi adalah dengan menggunakan $L M$ test yang disediakan oleh E-Views. Dari uji Autokorelasi menggunakan LM test diperoleh hasil sebagai berikut:

Tabel. 4. Hasil Correlation LM Test

\begin{tabular}{ccccc}
$\begin{array}{c}\text { F-statistic } \\
\text { Obs*R-squared }\end{array}$ & $\begin{array}{c}166.9662 \\
33.06815\end{array}$ & \multicolumn{2}{c}{$\begin{array}{c}\text { Probability } \\
\text { Probability }\end{array}$} & 0.000000 \\
\hline \hline Variable & Coefficient & Std. Error & t-Statistic & Prob. \\
\hline \hline$C$ & -1085.134 & 1559.552 & -0.695798 & 0.4911 \\
$D P K$ & -0.019411 & 0.019052 & -1.018851 & 0.3153 \\
$N P F$ & -0.529083 & 0.450094 & -1.175493 & 0.2477 \\
SBIS & 1.138119 & 0.440344 & 2.584615 & 0.0141 \\
RESID(-1) & 0.954752 & 0.073888 & 12.92154 & 0.0000 \\
\hline \hline$R$-squared & 0.826704 & \multicolumn{2}{c}{ Mean dependent var } & $-5.82 E-12$
\end{tabular}


Faktor-Faktor Yang Mempengaruhi Penyaluran Pembiayaan Perbankan Syariah Di Indonesia Periode 2009 - 2019

\begin{tabular}{cccc} 
Adjusted R-squared & 0.806898 & S.D. dependent var & 9107.127 \\
S.E. of regression & 4001.975 & Akaike info criterion & 19.54343 \\
Sum squared resid & $5.61 E+08$ & Schwarz criterion & 19.75454 \\
Log likelihood & -385.8686 & F-statistic & 41.74155 \\
Durbin-Watson stat & 1.428479 & Prob(F-statistic) & 0.000000 \\
\hline
\end{tabular}

Berdasarkan uji Autokorelasi dengan LM test diperoleh hasil bahwa nilai Probability $O b s^{*} R$-squared $=0.000000<0.05$. Dengan demikian keputusan yang diambil adalah ada autokorelasi positif.

Oleh karena itu perlu dilakukan pengobatan autokorelasi dengan menggunakan "Cochrane-Orcutt Procedure". Setelah dilakukan pengobatan autokorelasi diperoleh hasil seperti dipaparkan pada tabel berikut:

Tabel. 5. Hasil Correlation LM Test

Setelah diobati dengan Cochrane-Orcutt Procedure

\begin{tabular}{|c|c|c|c|c|}
\hline \multirow{3}{*}{$\begin{array}{c}\begin{array}{c}F \text {-statistic } \\
\text { Obs }{ }^{*} R \text {-squared }\end{array} \\
\text { Variable }\end{array}$} & \multirow{3}{*}{$\begin{array}{l}0.033138 \\
0.040577 \\
\text { Coefficient }\end{array}$} & \multirow{2}{*}{\multicolumn{2}{|c|}{$\begin{array}{l}\text { Probability } \\
\text { Probability }\end{array}$}} & \multirow{3}{*}{$\begin{array}{c}0.856738 \\
0.840357 \\
\text { Prob. }\end{array}$} \\
\hline & & & & \\
\hline & & Std. Error & $t$-Statistic & \\
\hline$C$ & 5356.240 & 180070.5 & 0.029745 & 0.9765 \\
\hline$D P K$ & 0.001196 & 0.096196 & 0.012436 & 0.9902 \\
\hline$N P F$ & -0.021057 & 0.838097 & -0.025125 & 0.9801 \\
\hline$S B I S$ & -0.015163 & 0.290646 & -0.052170 & 0.9587 \\
\hline$A R(1)$ & -0.063728 & 0.388764 & -0.163924 & 0.8709 \\
\hline$A R(2)$ & 0.062926 & 0.384116 & 0.163820 & 0.8709 \\
\hline $\operatorname{RESID}(-1)$ & 0.079590 & 0.437217 & 0.182038 & 0.8567 \\
\hline$R$-squared & 0.001068 & $\overline{\text { Mean d }}$ & endent var & $7.83 E-08$ \\
\hline Adjusted R-squared & -0.192274 & S.D. & ndent var & 2905.748 \\
\hline S.E. of regression & 3172.824 & Akaike & o criterion & 19.12745 \\
\hline Sum squared resid & $3.12 E+08$ & Schwo & criterion & 19.42911 \\
\hline Log likelihood & -356.4216 & & tistic & 0.005523 \\
\hline Durbin-Watson stat & 1.929701 & Probl & statistic) & 0.999999 \\
\hline
\end{tabular}

Berdasarkan uji Autokorelasi setelah pengobatan diperoleh hasil bahwa nilai Probability $O b s^{*} R$-squared $=0.840357>0.05$, sementara nilai Residual-nya telah berubah dari 0.954752 menjadi 0.079590 . Dengan demikian keputusan yang diambil adalah tidak ada autokorelasi positif maupun negatif.

\section{Uji Heteroskedastisitas}


Uji Heteroskedastisitas bertujuan untuk menguji apakah dalam model regresi terjadi ketidaksamaan variance dari residual satu pengamatan ke pengamatan yang lain. Jika variance dari residual satu pengamatan ke pengamatan yang lain berbeda maka disebut heteroskedastisitas (Ghozali, 2009). Untuk mendeteksi ada atau tidaknya heteroskedastisitas didalam model regresi antara lain dapat dilakukan dengan Uji Glejser, yakni meregresikan absolut nilai residual sebagai variabel dependen dengan variabel independen. Jika probabilitas signifikansinya diatas tingkat kepercayaan 5\% maka tidak terdapat heteroskedastisitas (Ghozali, 2009). Hasil Uji White Heteroskedastisitas:

Tabel. 6. Hasil Uji Heteroskedastisitas

White Heteroskedasticity Test:

\begin{tabular}{cccc}
\hline \hline F-statistic & 1.192805 & Probability & 0.335985 \\
Obs*R-squared & 7.127415 & Probability & 0.309225 \\
\hline \hline
\end{tabular}

Berdasarkan Uji Heteroskedastisitas diperoleh hasil bahwa variabel DPK, NPF, dan SBIS bebas dari heteroskedastisitas yang ditunjukkan dengan tingkat signifikansi Probability $O b s^{*} R$-squared $0.309225>0.05$, maka diambil kesimpulan: tidak terjadi Heteroskedastisitas

\section{Pengujian Hipotesis}

Hasil analisis dan pengujian hipotesis dapat dijelaskan sebagai berikut:

Uji-t (Uji Individual)

Uji-t digunakan untuk mengetahui apakah masing-masing koefisien regresi yang dihasilkan, layak atau tidak layak (signifikan atau tidak). Dari hasil estimasi regresi linier berganda di peroleh hasil berikut:

Tabel. 7. Hasil Awal Estimasi Regresi Linier Berganda

\begin{tabular}{ccccc} 
Variable & Coefficient & Std. Error & t-Statistic & Prob. \\
\hline \hline C & 191932.5 & 174943.8 & 1.097110 & 0.2808 \\
DPK & 0.512664 & 0.094510 & 5.424457 & 0.0000 \\
NPF & 1.020172 & 0.817441 & 1.248007 & 0.2211 \\
SBIS & -1.040586 & 0.274215 & -3.794786 & 0.0006 \\
\hline R-squared & 0.998745 & Mean dependent var & 175876.2 \\
Adjusted R-squared & 0.998549 & S.D. dependent var & 82034.59 \\
S.E. of regression & 3124.524 & Akaike info criterion & 19.07589 \\
Sum squared resid & $3.12 E+08$ & Schwarz criterion & 19.33446 \\
Log likelihood & -356.4419 & F-statistic & 5094.631 \\
Durbin-Watson stat & 1.914762 & Prob(F-statistic) & 0.000000 \\
\hline \hline
\end{tabular}


Dari tabel 7 di atas disusun persamaan regresi linier berganda sebagai berikut:

$$
\begin{aligned}
& \mathrm{PYD}=\mathrm{C}(1)+\mathrm{X}(1) * \mathrm{DPK}+\mathrm{X}(2) * \mathrm{NPF}-\mathrm{X}(3) * \mathrm{SBIS} \\
& \mathrm{PYD}=191932.5+0.512664 * \mathrm{DPK}+1.020172 * \mathrm{NPF}-1.040586 * \mathrm{SBIS}
\end{aligned}
$$

Berdasarkan persamaan regresi linier berganda di atas diperoleh koefisien regresi DPK sebesar (+) 0.512664. Koefisien tersebut mengindikasikan adanya hubungan positif antara variabel DPK terhadap pembiayaan yang disalurkan (PYD). Koefisien regresi NPF sebesar (+)1.020172. Koefisien tersebut mengindikasikan adanya hubungan positif antara variabel NPF terhadap PYD. Koefisien regresi SBIS sebesar (-)1.040586. Koefisien tersebut mengindikasikan adanya hubungan negatif antara variabel SBIS terhadap PYD.

Dari hasil Uji-t menunjukkan bahwa DPK berpengaruh positif terhadap pembiayaan yang disalurkan oleh perbankan Syariah. Berdasarkan Uji-t diperoleh hasil koefisien regresi DPK sebesar (+) 0.512664 dengan tingkat signifikansi 0,000. Karena tingkat signifikansi lebih kecil dari 0.05, maka secara parsial variabel independen DPK berpengaruh positif dan signifikan terhadap variabel dependen pembiayaan yang disalurkan oleh Perbankan Syariah.

Dari hasil Uji-t diketahui bahwa NPF berpengaruh positif terhadap pembiayaan yang disalurkan Perbankan Syariah. Berdasarkan Uji-t diperoleh hasil koefisien regresi NPF sebesar (+)1.020172 dengan tingkat signifikansi 0.2211. Karena tingkat signifikansi lebih besar dari 0.05 dan nilai koefisien regresi bertanda positif, maka secara parsial variabel independen NPF berpengaruh positif dan tidak signifikan terhadap variabel dependen pembiayaan yang disalurkan Perbankan Syariah.

Dari hasil Ujit diatas ditemukan bahwa SBIS berpengaruh negatif terhadap pembiayaan yang disalurkan Perbankan Syariah. Berdasarkan Uji-t diperoleh hasil bahwa nilai koefisien regresi SBIS sebesar (-)1.040586 dengan tingkat signifikansi 0.0006. Karena tingkat signifikansi lebih kecil dari 0.05 maka secara parsial variabel independen SBIS berpengaruh negatif dan signifikan terhadap variabel dependen pembiayaan yang disalurkan Perbankan Syariah. Dengan demikian hipotesis diterima.

\section{Uji -F (Uji Serentak)}

Digunakan untuk mengetahui apakah semua variabel bebas secara serentak berpengaruh signifikan terhadap variable tidak bebas.

\section{Hipotesa:}

Ho: tidak ada pengaruh semua variable bebas secara serentak terhadap variabel tidak bebas bebas.

Ha: ada pengaruh semua variable bebas secara serentak Terhadap variabel tidak

Bila prob $F$-stat $>0.05$ maka Ho diterima, Ha tidak diterima

Bila prob F-Stat < 0.05 maka Ho tidak diterima, Ha diterima,

Prob F-stat: $0.000000<0.05$, Ho ditolak, Ha diterima 
Dari hasil uji hipotesa di atas dapat diambil kesimpulan bahwa ada pengaruh signifikan dari semua variable bebas (DPK, NPF dan SBIS) secara serentak terhadap variabel tidak bebas (PYD).

\section{Uji Determinasi $\left(\mathbf{R}^{2}\right)$}

Dari hasil regresi berganda di atas diketahui bahwa koefisien Adjusted R-Squared $=0.998549$ atau $99.8549 \%$. Hal tersebut berarti menunjukkan kemampuan variable bebas (DPK, NPF dan SBIS) dalam menjelaskan perubahan variable tidak bebas (PYD) adalah sebesar $99.8549 \%$. Sedangkan sisanya $0.1451 \%$ dijelaskan oleh faktor lain di luar model seperti CAR, inflasi dan lainnya.

\section{Variabel Dana Pihak Ketiga (DPK)}

Dari hasil pengolahan data dalam penelitian ini menunjukkan bahwa peningkatan atau penurunan DPK selama periode penelitian mempengaruhi penyaluran pembiayaan secara positif dan signifikan. Ini berarti semakin tinggi DPK yang berhasil dihimpun oleh perbankan, akan mendorong peningkatan jumlah pembiayaan yang disalurkan, demikian pula sebaliknya, jika terjadi penurunan DPK maka pembiayaan juga akan mengalami penurunan. Maka dari itu kesimpulan yang diambil (X1): DPK berpengaruh positif terhadap pembiayaan perbankan, diterima).

Dari hasil regresi berganda di atas menjelaskan bahwa jika variabel DPK naik satu miliar maka akan menyebabkan kenaikan PYD sebesar 0.513 miliar rupiah.

Penyaluran dana untuk pembiayaan menjadi prioritas utama bagi Bank Syariah dalam pengalokasian dananya. Hal ini dikarenakan sumber dana Bank Syariah berasal dari masyarakat sehingga Bank Syariah harus menyalurkan kembali DPK yang berhasil dihimpun kepada masyarakat dalam bentuk pembiayaan. Hal ini sejalan dengan fungsi utama bank sebagai perantara keuangan (financial intermediary). Disamping itu penyaluran pembiayaan merupakan aktivitas yang paling utama bagi Bank Syariah selaku business entity untuk menghasilkan keuntungan bagi kedua belah pihak. Pengalaman dan kemampuan pembiayaan yang dimiliki juga turut mendukung keberanian Bank Syariah di Indonesia dalam menyalurkan pembiayaan.

DPK merupakan variabel yang memiliki pengaruh paling besar terhadap penyaluran pembiayaan yang dilakukan Perbankan Syariah. Hal ini dikarenakan dalam menjalankan fungsi perantara keuangan (financial intermediary), DPK merupakan sumber pendanaan utama. Dana-dana yang dihimpun dari masyarakat dapat mencapai 80\%-90\% dari seluruh dana yang dikelola oleh bank (Dendawijaya, 2005).

\section{Variabel Non Performing Financing (NPF)}

Hasil pengolahan data dalam penelitian ini menegaskan bahwa peningkatan atau penurunan NPF selama periode penelitian mempengaruhi penyaluran pembiayaan secara signifikan. Dalam hal ini NPF Perbankan Syariah berbeda dengan NPL perbankan konvensional. NPF Perbankan Syariah lebih stabil dibandingkan dengan NPL perbankan konvensional. Bank Syariah mampu menjaga NPF dalam kisaran 2\%-4\% atau dibawah kisaran 5\%, Hal ini yang menjadikan NPF dalam perbankan syariah bernilai positif dan tidak signifikan terhadap penyaluran dana kepada masyarakat. Besaran nilai NPF seiring dengan jumlah pembiayaan yang disalurkan oleh Bank Syariah. Artinya, kenaikan NPF 
diikuti oleh kenaikan dan peningkatan penyaluran pembiayaan Perbankan Syariah kepada masyarakat. Oleh sebab itu kesimpulan yang diambil (NPF berpengaruh positif terhadap pembiayaan perbankan, diterima).

Dari hasil regresi berganda di atas menjelaskan bahwa jika variabel NPF naik satu miliar maka akan menyebabkan kenaikan PYD sebesar 1.02 milliar.

Aspek transparansi, nilai-nilai kejujuran dan kepercayaan yang dibangun antara masyarakat dan Bank Syariah terbukti dapat menekan angka Non Performing Financing (NPF) bertahan dibawah 5\%. NPF adalah risiko setiap pembiayaan. Namun kenaikan tingkat NPF dalam perbankan syariah seiring dengan kenaikan tingkat pembiayaan yang disalurkan oleh perbankan kepada masyarakat. Dengan demikian Perbankan Syariah tidak kuatir dengan kenaikan NPF dalam penyaluran pembiayaan. Ini berarti potensi pembiayaan yang tidak tertagih cukup kecil dalam Perbankan Syariah.

Hal ini berbeda dengan NPL dalam perbankan konvensional, tingginya NPL dalam bank konvensional akan meningkatkan premi risiko yang berdampak pada tingginya suku bunga kredit. Suku bunga kredit yang terlampau tinggi akan mengurangi permintaan masyarakat akan kredit. Tingginya NPL juga mengakibatkan munculnya pencadangan yang lebih besar, sehingga pada akhirnya modal bank ikut terkikis. Padahal besaran modal sangat mempengaruhi besarnya ekspansi kredit.

Dengan demikian besarnya NPF dalam Bank Syariah tidak menjadi faktor penghambat bagi penyaluran pembiayaan yang dilakukan oleh perbankan syariah di Indonesia.

\section{Variabel Sertifikat Bank Indonesia Syariah (SBIS)}

Hasil pengolahan data dalam penelitian ini mengindikasikan bahwa peningkatan atau penurunan SBIS selama periode penelitian berpengaruh negatif terhadap pembiayaan yang disalurkan oleh Perbankan Syariah Indonesia secara signifikan. Maka kesimpulan yang diambil (SBIS berpengaruh negatif terhadap pembiayaan perbankan, diterima).

Dalam penelitian ini menunjukkan bahwa dana yang disalurkan pada SBIS tidak konsisten, sehingga penurunan dan peningkatan penempatan dana pada SBIS tidak searah dengan kenaikan pembiayaan dan DPK.

Dari hasil regresi berganda di atas menjelaskan bahwa jika variabel SBIS naik satu miliar maka akan menyebabkan penurunan PYD sebesar 1.04 milliar.

Hal ini terjadi karena pada dasarnya SBI Syariah hanyalah sebagai instrumen alternatif sementara, pada saat bank syariah mengalami over likuiditas. Hal tersebut sesuai dengan ketentuan umum fatwa DSN MUI No. 63/DSN-MUI/XII/2007 tentang Sertifikat Bank Indonesia Syariah (SBIS) yang mengatakan bahwa Bank Syariah boleh memiliki SBIS untuk memanfaatkan dananya yang belum dapat disalurkan ke sektor riil. Ketika bank mampu menyalurkan dananya ke pembiayaan secara maksimal, maka akan semakin kecil tingkat likuiditasnya, sehingga kelebihan likuiditas yang ditempatkan pada SBIS akan semakin kecil.

Sementara itu pemberian bonus atas penitipan dana wadiah merupakan kewenangan Bank Indonesia (Peraturan Bank Indonesia No.6 Th 2004 tentang SWBI). Demikian juga imbalan atas penempatan dana Bank Syariah pada SBIS, pada prinsipnya 
Bank Indonesia menetapkan dan memberikan imbalan atas SBIS yang diterbitkan (Peraturan Bank Indonesia No.10 Th 2008 tentang SBIS). Maka dapat dikatakan bahwa baik pemberian bonus SWBI atau imbalan SBIS dari penempatan dana Bank Syariah atau pun Unit Usaha Syariah tergantung kepada kebijakan serta anggaran dana yang dimiliki oleh Bank Indonesia sebagai tempat penitipan dana wadiah atau SBI Syariah dari Bank Syariah dan Unit Usaha Syariah. Sementara Bank Syariah dan Unit Usaha Syariah tidak mempunyai kekuatan untuk meminta kepada Bank Indonesia akan bonus atau imbalan yang dijanjikan oleh Bank Indonesia. Hal ini pula yang mendorong Bank Syariah lebih tertarik pada penyaluran dana kepada sektor riil dibandingkan pada SBIS.

\section{KESIMPULAN}

Dari hasil proses analisis data dan pembahasan yang telah dipaparkan di atas dapat diambil kesimpulan sebagai berikut:

Secara parsial variabel DPK berpengaruh positif dan signifikan terhadap variabel pembiayaan yang disalurkan oleh Perbankan Syariah di Indonesia. Variabel NPF berpengaruh positif dan tidak signifikan terhadap variabel pembiayaan yang disalurkan. Variabel SBIS berpengaruh negatif dan signifikan terhadap variabel pembiayaan yang disalurkan oleh Bank Syariah Indonesia.

Secara serentak variabel DPK, NPF dan SBIS berpengaruh signifikan terhadap variabel PYD Bank Syariah Indonesia.

\section{REFERENSI}

Amrillah, M. Agus.2011. Analisis Komparasi Aplikasi Pinjaman Kredit Pemilikan Rumah (KPR) Dan Pembiayaan Kredit Pemilikan Rumah Syariah (KPRS) Pada Perusahaan Perbankan Di Malang. Malang: Universitas Islam Negeri Maulana Malik Ibrahim.

Anshori, Abdul Ghofur. Perbankan Syariah Indonesia. Yogyakarta: Gajah Mada University Press.

Antonio, M.S. 2005. Bank Syariah: Dari Teori ke Praktik. Jakarta: Gema Insani Press

Arifin, Zainul.2006. Dasar-dasar Manajemen Bank Syariah. Jakarta: Pustaka Alvabet.

Arifin, Zainul. 2009. Dasar-Dasar Manajemen Bank Syariah. Ciputat: Plaza Mas.

Bambang, Budhijana R. 2012. Faktor-Faktor Kelembagaan yang Mempengaruhi Kinerja Perbankan Syariah di Indonesia 2000-2011. Jakarta: Universitas Taruma Negara.

Ghazali, Imam. 2007. Pengaruh CAR (Capital Adequacy Ratio), FDR (Financing to Deposit Ratio), BOPO (Biaya Operasional terhadap Pendapatan Operasional) dan NPL (Non-Performing Loan) terhadap Profitabilitas Bank Syariah Mandiri (Januari: 2004 - Oktober: 2006). Yogyakarta: Fakultas Ekonomi Universitas Islam Indonesia.

Ismail. 2011. Perbankan Syariah. Jakarta: Kencana Prenada Media Group.

Karim, Adiwarman. 2011. Bank Islam; Analisis Fiqh dan Keuangan. Jakarta: Raja Grafindo Persada. 
Nachrowi, N.D., MSc., et.al.. 2006. Ekonometrika; Analisis Ekonomi dan Keuangan, Jakarta: FEUI.

Novianto, Abdullah Syakur. 2008. Analisis Pengaruh Dana Pihak Ketiga, Sertifikat Wadiah Bank Indonesia, Non Performing Financing Dan Inflasi Terhadap Pembiayaan Perbankan Syariah Di Indonesia. Surabaya: Universitas Airlangga.

Nusantara, Ahmad Buyung, 2009, Analisis Pengaruh NPL, CAR, LDR, dan BOPO Terhadap Profitabilitas Bank (Perbandingan Bank Umum Go Publik dan Bank Umum Non Go Publik di Indonesia Periode Tahun 2005-2007). Semarang, Universitas Diponegoro.

Nurjannah, Anis, 2010. Pengaruh Dana Pihak Ketiga, Modal Sendiri, Margin Keuntungan, Dan Non Performing Financing Terhadap Pembiayaan Murabahah Pada Perbankan Syariah. Yogyakarta: Unversitas Ahmad Dahlan.

Peraturan Bank Indonesia, Nomor: 12/ 18 /PBI/2010 Tentang Perubahan Atas Peraturan Bank Indonesia Nomor: 10/11/PBI/2008 Tentang Sertifikat Bank Indonesia Syariah.

Pratama, Billy Arma. 2010. Analisis Faktor - Faktor Yang Mempengaruhi Kebijakan Penyaluran Kredit Perbankan; (Studi pada Bank Umum di Indonesia Periode Tahun 2005 - 2009). Semarang: UNDIP.

Siregar, Nurhayati. 2004. Analisis Faktor-faktor yang Mempengaruhi Penyaluran dana Perbankan Syariah Indonesia. Sumatra Utara: USU.

Soemitra, Andri. 2010. Bank dan Lembaga Keuangan Syariah. Jakarta: Kencana Prenada Media Group.

Sofyan, Sofriza. 2011. Business Data Analysis dan Econometrics. Jakarta: Universitas Az-Zahra.

Sutedi, Adrian. 2009. Perbankan Syariah: Tinjauan dan Beberapa Segi Hukum. Jakarta: Ghalia Indonesia.

www.bi.go.id. Statistik Perbankan Syariah Indonesia.

www.bi.go.id. Indikator Perbankan Nasional

www.bi.go.id. Statistik Ekonomi Moneter Indonesia

www.ojk.go.id. Statistik Perbankan Syariah 